\title{
Transport of chloramphenicol into sensitive strains of Escherichia coli and Pseudomonas aeruginosa
}

\author{
Saad Abdel-Sayed \\ Institut de Microbiologie de l'Université de Lausanne, Centre Hospitalier Universitaire \\ Vaudois, Rue du Bugnon 44, 1011 Lausanne, Switzerland
}

\begin{abstract}
The uptake of chloramphenicol by susceptible strains of Escherichia coli and Pseudomonas aeruginosa was measured as the depletion of ${ }^{14} \mathrm{C}$-chloramphenicol from the supernatant of centrifuged cultures. Chloramphenicol did not bind to nongrowing cells or isolated cell envelopes. Chloramphenicol was recovered from cells in an unchanged form and was intracellularly concentrated several times above external concentrations. The net accumulation of the drug was reduced by an inhibitor of electron transport, by an oxidative phosphorylation uncoupler, by an inhibitor of high energy phosphate synthesis, and by lowering the temperature to $+15^{\circ} \mathrm{C}$. The initial uptake of drug was saturated at $1.98 \mathrm{~mm}$ chloramphenicol in the medium. A 100-fold excess of each of the unlabelled isomers: L-threo, D-threo, and L-erythro chloramphenicol in cultures of either strain effectively reduced the uptake of ${ }^{14} \mathrm{C}$-chloramphenicol. These results indicate that chloramphenicol enters Gramnegative bacteria by means of an energy-dependent process.
\end{abstract}

\section{Introduction}

Chloramphenicol is an antibiotic that inhibits protein synthesis in procaryotic cells. It binds primarily to protein L 16 of bacterial ribosomes and blocks peptide bond formation by inactivating peptidyltransferase (Nierhaus \& Nierhaus, 1973). Since the target for chloramphenicol is intracellular, the drug must penetrate the cell envelope of bacteria.

The accumulation of chloramphenicol by Staphylococcus aureus strain Duncan and Bacillus megaterium strain KM (NCIB 9521) was described by Vasquez (1963, 1966). He showed that the rate of uptake was initially high but fell rapidly and that after two minutes a much slower rate was established. The magnitude of uptake was directly related to the external drug concentration and could be greatly reduced by peptidyl transferase inhibitors such as ostreogrycins group A and group B, but was unaffected by tetracyclines, inhibitors of the binding of aminoacyl-tRNA to the $30 \mathrm{~S}$ ribosomal subunit or by puromycin, an inhibitor of peptide chain elongation functioning as an analogue of terminal aminoacyl-tRNA.

Irvin \& Ingram (1980) isolated two chloramphenicol-resistant mutants of Pseudomonas aeruginosa which also exhibited decreased amino-acid accumulation. Neither of these mutants inactivate chloramphenicol by acetylation and both possess ribosomes sensitive to the action of chloramphenicol. Since uptake of amino-acids by bacteria involves active transport (Anraku, 1978), the data of Irvin \& Ingram (1980) could be interpreted as showing an energy-dependent chloramphenicol uptake.

7 
However, the chloramphenicol-resistant mutants may accumulate decreased amounts of amino-acids and chloramphenicol owing to loss of outer membrane porins (Foulds \& Chai, 1978; Pugsley \& Schnaitman, 1978). Thus, the evidence for active accumulation of chloramphenicol remains equivocal.

Bacterial resistance to chloramphenicol can be produced by at least three different mechanisms: enzymatic covalent modification of the molecular structure, alteration of the cells' permeability, and alteration of the ribosomal binding site (Foster, 1983). Studies on the uptake of chloramphenicol by a number of Gram-positive bacteria that do not covalently modify it have shown that there is a correlation between the rate of uptake of the antibiotic by the organisms and their sensitivity to it (Vasquez, 1964). In all the studies reported above the cells were washed to remove external molecules before intracellular concentration of chloramphenicol was determined. Chloramphenicol is so weakly held in the cells that washing itself can remove intracellular antibiotic (Vasquez, 1963, 1964). In the investigation of chloramphenicol transport into bacteria reported here a centrifugation method was used to determine chloramphenicol uptake without washing of the cells.

\section{Materials and methods}

\section{Bacterial strains}

The organisms used for this study were Escherichia coli $\mathrm{K} 12$ strain 703 (Hammersmith wild type $\mathrm{F}^{-}$) and $P$. aeruginosa ATCC 9027 . The MIC of chloramphenicol for the $E$. coli strain was $6.25 \mathrm{mg} / \mathrm{l}$, and for the $P$. aeruginosa strain $25 \mathrm{mg} / 1$, determined by dilution technique in $\mathrm{BYGNaCl}$ medium (see below).

\section{Media and growth conditions}

The organisms were maintained on nutrient agar slants at room temperature. When used for experiments, cells were grown aerobically until mid-exponential phase at $37^{\circ} \mathrm{C}$ on a gyratory Adolf Kühner shaker at 250 r.p.m. Erlenmeyer flasks $(100 \mathrm{ml})$ each containing $30 \mathrm{ml}$ of growth medium, $\mathrm{BYGNaCl}$ medium: $13 \mathrm{~g}$ nutrient broth (Oxoid), $5 \mathrm{~g}$ yeast extract (BBL), $5 \mathrm{~g} \mathrm{NaCl}, 1 \mathrm{~g}$ glucose per litre, adjusted to $\mathrm{pH} 7$ (Lennox, 1955), was used for most of these studies. Where noted a BM2 medium composed of $2.5 \mathrm{~g}$ glucose, $7 \mathrm{~g} \mathrm{~K}_{2} \mathrm{HPO}_{4}, 3.4 \mathrm{~g} \mathrm{KH}_{2} \mathrm{PO}_{4}, 1 \mathrm{~g}\left(\mathrm{NH}_{4}\right) \mathrm{SO}_{4}$, and $0.024 \mathrm{~g} \mathrm{MgSO}_{4} . \mathrm{H}_{2} \mathrm{O}$ per litre was used (Gilleland, Stinett \& Eagon, 1974).

\section{Chloramphenicol uptake}

Cells grown in $\mathrm{BYGNaCl}$ medium were harvested by centrifugation at 6000 r.p.m. for $10 \mathrm{~min}$ and then resuspended in the same volume of unused prewarmed $\mathrm{BYGNaCl}$ medium at $37^{\circ} \mathrm{C}$. Of this suspension $1-1.8 \mathrm{ml}$ were transferred to $25-\mathrm{ml}$ Erlenmeyer flasks, and a mixture of ${ }^{14} \mathrm{C}$-chloramphenicol $(46.9 \mathrm{mCl} / \mathrm{mmol})$ with unlabelled chloramphenicol was added to produce final volumes of $2 \mathrm{ml}$ with various concentrations of chloramphenicol. Final specific activities ranged from 0.63 to $32.3 \mathrm{mCi} / \mathrm{mmol}$. The flasks were incubated at $37^{\circ} \mathrm{C}$ on a reciprocal shaking water bath. At $5 \mathrm{~min}$ intervals, aliquots of $0.2 \mathrm{ml}$ were removed and centrifuged in a Kontron centrifuge (type Hermle z635-K) at 6000 r.p.m. for $1 \mathrm{~min}$ at $25^{\circ} \mathrm{C}$. The upper $0.1 \mathrm{ml}$ of the supernatant was carefully removed to a scintillation vial containing $10 \mathrm{ml}$ of 
scintillation fluid. This was composed of ethanol, Triton X-100 and toluene in the ratio of $1: 3.3: 5.7$ containing $0.572 \%(w / v)$ diphenyloxazole and $0.014 \%(w / v) 1.4-b i s[2-(4-$ methyl-5-phenyloxazonyl)]-benzene. The radioactivity was determined with a Unilux model scintillation spectrometer (Nuclear Chicago). The amount of cell-associated chloramphenicol was determined by subtracting the amount of the residual ${ }^{14} \mathrm{C}$ chloramphenicol in the supernatant from the amount of ${ }^{14} \mathrm{C}$-chloramphenicol in the cell suspension.

\section{Radiochemical purity}

The cells from $20 \mathrm{ml}$ of actively growing culture were suspended in $2 \mathrm{ml}$ of unused $\mathrm{BYGNaCl}$ medium maintained at $37^{\circ} \mathrm{C} .{ }^{14} \mathrm{C}$-Chloramphenicol was added to produce a specific activity of $2.5 \mathrm{mCi} / \mathrm{l}$ and the cell suspension was incubated at $37^{\circ} \mathrm{C}$ on a reciprocal shaking water bath. After $5 \mathrm{~min}$ of labelling the cells were harvested by filtration on Millipore membrane filters and immediately washed by filtering $2.5 \mathrm{ml}$ of $0.1 \mathrm{M} \mathrm{NaCl}$. The membrane filters bearing the cells were transferred to $25-\mathrm{ml}$ Erlenmeyer flasks containing $3 \mathrm{ml}$ distilled water and the cells were detached from the filter membranes by magnetic stirring. The cell suspension was then submitted to three successive extractions with $3 \mathrm{ml}$ diethyl ether. The pooled extracts were evaporated to dryness in an air stream. The samples, dissolved in $0.1 \mathrm{ml}$ ethyl acetate, were spotted by repeated applications of a total volume of $0.02 \mathrm{ml}$ at the origin of a thin layer silica gel (Kisel gel $60 \mathrm{~F} 245,0.25 \mathrm{~mm}$, Merck) alongside a control preparation of ${ }^{14} \mathrm{C}$ chloramphenicol. The sheets were submitted to ascending chromatography in a chloroform : methanol $90: 10(\mathrm{v} / \mathrm{v})$ solvent system. The chromatograms were air dried and subjected to autoradiography for 66 hours with Kodak X-Omat AR-5 film.

\section{Measurement of protein synthesis}

Exponentially growing cells were harvested and resuspended in $\mathrm{BYGNaCl}$ medium at $37^{\circ} \mathrm{C}$ at $\mathrm{A}_{660}=0.67$. From this suspension, $0.97-\mathrm{ml}$ amounts were transferred to $25-\mathrm{ml}$ Erlenmeyer flasks containing $0.03 \mathrm{ml}(0.319 \mathrm{mCi})$ of ${ }^{35} \mathrm{~S}$-methionine with or without chloramphenicol. The flasks were rapidly mixed and subsequently held on a reciprocal shaking water bath at $37^{\circ} \mathrm{C}$. At time intervals, samples of $0.05 \mathrm{ml}$ were removed and spotted on to Whatman no. $3 \mathrm{MM}$ discs pretreated with trichloroacetic acid. After drying at room temperature, all discs were processed simultaneously as described by Levy (1971) to evaluate ${ }^{35}$ S-methionine incorporated into trichloroacetic acidprecipitable protein.

\section{Cells preincubated in medium unable to support growth}

Cells grown in $\mathrm{BYGNaCl}$ medium were harvested by centrifugation and washed three times with $50 \mathrm{~mm}$ phosphate buffer, $\mathrm{pH} 7$. Washed cells were suspended to the original volume of the same buffer and incubated at $37^{\circ} \mathrm{C}$ with shaking for $2 \mathrm{~h}$. The cells were centrifuged and resuspended in $1 \mathrm{ml}$ phosphate buffer per $\mathrm{mg}$ of cell protein for equilibrium dialysis. 
Transport assays

The uptake of $\left[\mathrm{U}-{ }^{14} \mathrm{C}\right]$ protein hydrolysate by both strains was determined at $37^{\circ} \mathrm{C}$ to check the active accumulation of amino-acids by cells preincubated in medium unable to support growth. Cells were washed as described above and suspended in $50 \mathrm{~mm}$ phosphate buffer, $\mathrm{pH} 7$, to a density of $2 \mathrm{~g}$ wet weight per $10 \mathrm{ml}$. The suspensions were used for uptake assays. The uptake mixtures contained $0.2 \mathrm{ml}$ of cell suspension and 4.4 nanoatom carbon of [U- ${ }^{14} \mathrm{C}$ ] protein hydrolysate $(5.7 \mathrm{mCi} / \mathrm{milliatom}$ carbon) in a final volume of $0.5 \mathrm{ml}$. The reaction was started by addition of substrate. At time intervals, $0.05 \mathrm{ml}$ samples were removed and delivered over membrane filters $(25 \mathrm{~mm}$ diameter; $0.45 \mu \mathrm{m}$ pore size; Millipore corporation, Bedford, MA, U.S.A.) which had been pretreated by filtering $5 \mathrm{ml} 0.1 \mathrm{M} \mathrm{LiCl}$. The samples were filtered instantaneously and the filters were immediately washed with $5 \mathrm{ml} 0.1 \mathrm{M} \mathrm{LiCl}$. The filters bearing the cells were removed from the suction apparatus and transferred to vials containing $10 \mathrm{ml}$ of the scintillation fluid. The radioactivity was determined as described above.

\section{Spheroplast preparation and spheroplast uptake}

Spheroplasts were prepared from the $E$. coli strain according to the method of Weiss (1976) with slight modifications. Cells were grown in BYGNaCl medium. Deoxyribonuclease type I and II, and ribonuclease were added to a final concentration of $0.05 \mathrm{mg} / 1$ directly after the addition of lysozyme. Spheroplasts were harvested by centrifugation at $3600 \mathrm{~g}$ for $15 \mathrm{~min}$ and subsequently washed once with $0.1 \mathrm{M}$ Tris- $\mathrm{HCl}$ buffer, pH 8 , containing $20 \%$ sucrose. Washed spheroplasts were suspended into the original volume of a solution of $20 \%$ sucrose in $50 \mathrm{~mm}$ phosphate buffer, $\mathrm{pH} 7$, or in sucrose BYGNaCl medium. Samples of $1 \mathrm{ml}$ of these suspensions, when diluted ten times in water, decreased in optical density at $660 \mathrm{~nm}$ ten times more than that diluted in $20 \%$ sucrose. The spheroplast suspensions were used directly for uptake assays. The uptake mixtures contained $0.9 \mathrm{ml}$ of spheroplast suspension and $10 \mu \mathrm{g}$ of ${ }^{14} \mathrm{C}$ chloramphenicol $(6.16 \mathrm{mCi} / \mathrm{mmol})$ in a final volume of $1 \mathrm{ml}$. The reaction was started by the addition of substrate. After $5 \mathrm{~min}$ of incubation at $37^{\circ} \mathrm{C}, 0.2 \mathrm{ml}$ was removed and centrifuged at $3000 \mathrm{~g}$ for $2 \mathrm{~min}$. The upper $0.1 \mathrm{ml}$ of the supernatant was carefully removed and processed as described above to evaluate ${ }^{14} \mathrm{C}$-chloramphenicol incorporated into spheroplasts.

\section{Miscellaneous assays and techniques}

Protein was determined according to the method of Markwell et al. (1978). Cell envelopes were prepared as described by Hancock \& Nikaido (1978). Equilibrium dialysis was carried out in a multichamber apparatus by the procedure of Furlong et al. (1972).

\section{Reagents}

D-threo (dichloro-1,2- ${ }^{14} \mathrm{C}$ ) chloramphenicol $(46.9 \mathrm{mCi} / \mathrm{mmol})$ and ${ }^{35} \mathrm{~S}$-methionine (1058 Ci/mmol) were purchased from New England Nuclear Corp., Boston, Mass., U.S.A.; $\left[\mathrm{U}-{ }^{14} \mathrm{C}\right]$-Protein hydrolysate, composed of 16 amino-acids $(57 \mathrm{mCi} / \mathrm{milliatom}$ carbon), from Amersham, Buckinghamshire, England. Non-radioactive 
chloramphenicol was a gift from Le Petit Co., Milan, Italy. Chloramphenicol isomers were a gift from Warner Lambert Co., Ann Arbor, Mich. All other reagents were purchased from normal commercial sources.

\section{Results}

\section{Uptake of chloramphenicol}

Figure 1 illustrates the time course of the uptake of chloramphenicol for $E$. coli and $P$. aeruginosa in $\mathrm{BYGNaCl}$ medium at concentrations of 10 and $40 \mathrm{mg} / \mathrm{l}$ respectively. Uptake of the drug by either bacterium demonstrated biphasic kinetics: a rapid uptake, which ceased at the time the first sample was taken $(1 \mathrm{~min})$ and a slower uptake, which then continued for $5 \mathrm{~min}$; thereafter, the uptake reached a plateau of a period of 5-30 min. With a value of $2.7 \mathrm{ml}$ cell water per $\mathrm{g}$ dry weight of bacteria assumed (Winkler \& Wilson, 1966), the concentration of cell-associated chloramphenicol after $1 \mathrm{~min}$ of incubation for $E$. coli was $689.7 \mathrm{mg} / \mathrm{l}$ cell water at a chloramphenicol concentration in the medium of $10 \mathrm{mg} / \mathrm{l}$. For $P$. aeruginosa, the concentration of cell-associated chloramphenicol was $2595.3 \mathrm{mg} / 1$ cell water at a chloramphenicol concentration in the medium of $40 \mathrm{mg} / \mathrm{l}$. Thus, after $1 \mathrm{~min}$ of incubation the concentration of chloramphenicol accumulated by $E$. coli and $P$. aeruginosa reached about 69 and 65 times the concentration in the medium, respectively. After $5 \mathrm{~min}$ of uptake the concentration of chloramphenicol respectively accumulated by $E$. coli and $P$. aeruginosa exceeded about 140 and 97 times the concentration in the medium. Lowering the reaction temperature to $+15^{\circ} \mathrm{C}$ produced a marked change in both rates of uptake by either type of bacterium. Furthermore, the slow uptake appeared to last longer than usually seen at $37^{\circ} \mathrm{C}$ (Figure 1).

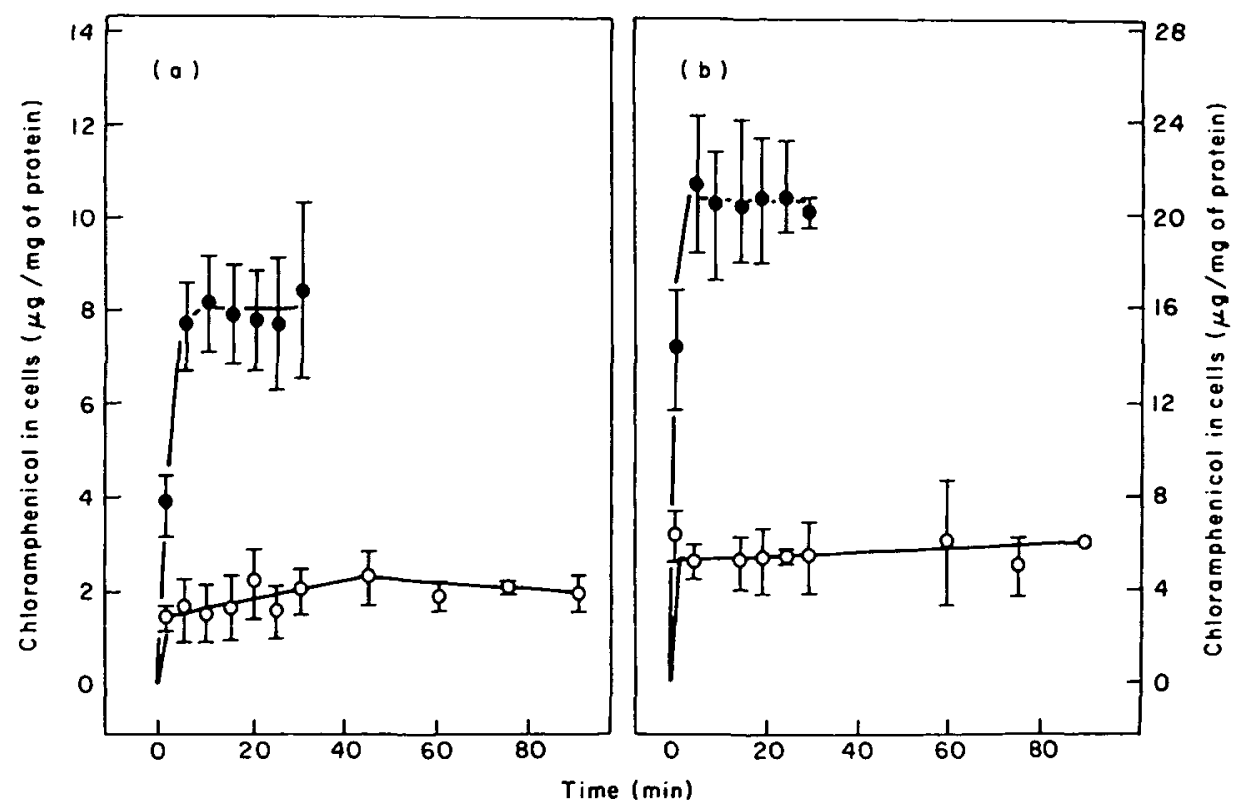

Figure 1. Uptake of chloramphenicol with time in $\mathrm{BYGNaCl}$ medium at $37^{\circ} \mathrm{C}(O)$, and $15^{\circ} \mathrm{C}(\mathrm{O})$, in the presence of $10 \mathrm{mg}$ chloramphenicol/l for $E$. coli (a) and $40 \mathrm{mg}$ chloramphenicol/l for $P$. aeruginosa (b). Bars represent standard errors of the mean for four experiments. 
Table I. Effect of unlabelled chloramphenicol and chloramphenicol isomers on

${ }^{14} \mathrm{C}$-chloramphenicol uptake by $E$. coli and $P$. aeruginosa

\begin{tabular}{llcc}
\hline Bacteria & $\begin{array}{c}\text { Unlabelled } \\
\text { substance }\end{array}$ & $\begin{array}{c}14 \mathrm{C}-\mathrm{CM} \text { taken up } \\
(\mu \mathrm{g} / \mathrm{mg} \text { protein })\end{array}$ & $\begin{array}{c}\text { \% inhibition } \\
\text { of uptake }\end{array}$ \\
\hline E. coli & Control & $132 \cdot 00 \pm 54 \cdot 00$ & 0 \\
& CM & 0 & 100 \\
& L-threo-CM & $45 \cdot 00 \pm 14 \cdot 00$ & 66 \\
& D-erythro-CM & 0 & 100 \\
& L-erthryo-CM & $25 \cdot 00 \pm 8.00$ & 81 \\
P. aeruginosa & Control & $73.00 \pm 10.00$ & 0 \\
& CM & $3 \cdot 15 \pm 2 \cdot 22$ & 96 \\
& L-threo-CM & $1 \cdot 30 \pm 1 \cdot 14$ & 98 \\
& D-erythro-CM & 0 & 100 \\
& L-erythro-CM & $25.00 \pm 8.00$ & 66 \\
\hline
\end{tabular}

${ }^{a} \mathrm{CM}$, chloramphenicol; in the presence of ${ }^{14} \mathrm{C}-\mathrm{CM}$ and unlabelled substance at concentrations of $3 \times 10^{-6} \mathrm{M}$ and $3 \times 10^{-4} \mathrm{M}$ respectively; accumulation period $1 \mathrm{~min}$ in $\mathrm{BYGNaCl}$ medium. Values were obtained from two experiments.

Measured after $1 \mathrm{~min}$, the uptake of ${ }^{14} \mathrm{C}$-chloramphenicol by either type of bacterium was greatly reduced by the unlabelled chloramphenicol isomers: $\mathrm{L}$-threo and L-erythro when each was added at 100 times the concentration of ${ }^{14} \mathrm{C}$-chloramphenicol (Table I). The unlabelled chloramphenicol and the D-erythro isomer completely inhibited the uptake of ${ }^{14} \mathrm{C}$-chloramphenicol. $\mathrm{MgSO}_{4}$ reduced the rate of uptake of chloramphenicol by both strains (Table II) and also elevated the MIC respectively two and four times for $E$. coli and $P$. aeruginosa, when added to a final concentration of $5 \mathrm{~mm}$. Similar results were obtained with $\mathrm{MgCl}_{2}$ (Table II) indicating that the

Table II. Inhibition of chloramphenicol uptake by magnesium sulphate

\begin{tabular}{|c|c|c|}
\hline Bacteria & $\begin{array}{c}\mathrm{Mg}^{++} \text {added } \\
(\mathrm{mM})\end{array}$ & $\begin{array}{c}\text { Cell associated CM } \\
(\mu \mathrm{g} / \mathrm{mg} \text { protein })\end{array}$ \\
\hline E. coll ${ }^{n}$ & $\begin{array}{l}0.00 \\
0.50 \\
1.00 \\
1.50 \\
2.00 \\
2.00\end{array}$ & $\begin{array}{c}7.85 \pm 0.15 \\
4.90 \pm 0.20 \\
4.10 \pm 0.60 \\
2.35 \pm 0.35 \\
1.85 \pm 0.05 \\
(1.10 \pm 0.14)^{c}\end{array}$ \\
\hline P. aeruginosa ${ }^{b}$ & $\begin{array}{l}0.00 \\
0.50 \\
1.00 \\
1.50 \\
2.00 \\
2.00\end{array}$ & $\begin{array}{l}21 \cdot 40 \pm 3 \cdot 00 \\
15.45 \pm 1 \cdot 25 \\
14 \cdot 70 \pm 3 \cdot 10 \\
13 \cdot 65 \pm 0.25 \\
11 \cdot 15 \pm 1 \cdot 55 \\
(6 \cdot 15 \pm 0 \cdot 21)\end{array}$ \\
\hline
\end{tabular}

$\mathrm{CM}$, chloramphenicol; "chloramphenicol concentration, $10 \mathrm{mg} / \mathrm{l}$, accumulation period, $5 \mathrm{~min}$ in $\mathrm{BYGNaCl}$ medium; "chloramphenicol concentration, $40 \mathrm{mg} / \mathrm{l}$; accumulation period, $5 \mathrm{~min}$ in $\mathrm{BYGNaCl}$ medium; 'the numbers in parentheses are the uptake of $\mathrm{CM}$ in the presence of $\mathrm{MgCl}_{2}$; values were obtained from two experiments. 
inhibition of chloramphenicol uptake by $\mathrm{MgSO}_{4}$ was due to $\mathrm{Mg}^{++}$effect and not to sulphate. Cells grown in minimal BM2 medium exhibited a reduced uptake of chloramphenicol compared with those grown in $\mathrm{BYGNaCl}$ medium, with values of $27 \%$ and $14 \%$ for $E$. coll and $P$. aeruginosa, respectively. Cells grown in BM2 medium were thus phenotypically more resistant. For example, the MIC for the $P$. aeruginosa strain harvested from BM2 medium was $100 \mathrm{mg} / 1$, whether the test medium was BM2 or $\mathrm{BYGNaCl}$. In contrast, cells grown in $\mathrm{BYGNaCl}$ and transferred into $\mathrm{BM} 2$ were not able to incorporate ${ }^{14} \mathrm{C}$-chloramphenicol.

\section{Chloramphenicol extracted from cells}

More than $90 \%$ of accumulated chloramphenicol was recovered from cells by ether extraction. Autoradiography of thin layer chromatograms demonstrated that the $R_{\mathrm{f}}$ value $(0.68)$ of extracted chloramphenicol was identical to that of a control preparation of ${ }^{14} \mathrm{C}$-chloramphenicol (Figure 2). These results clearly indicated that the majority of accumulated chloramphenicol was recovered from cells in an unchanged form.

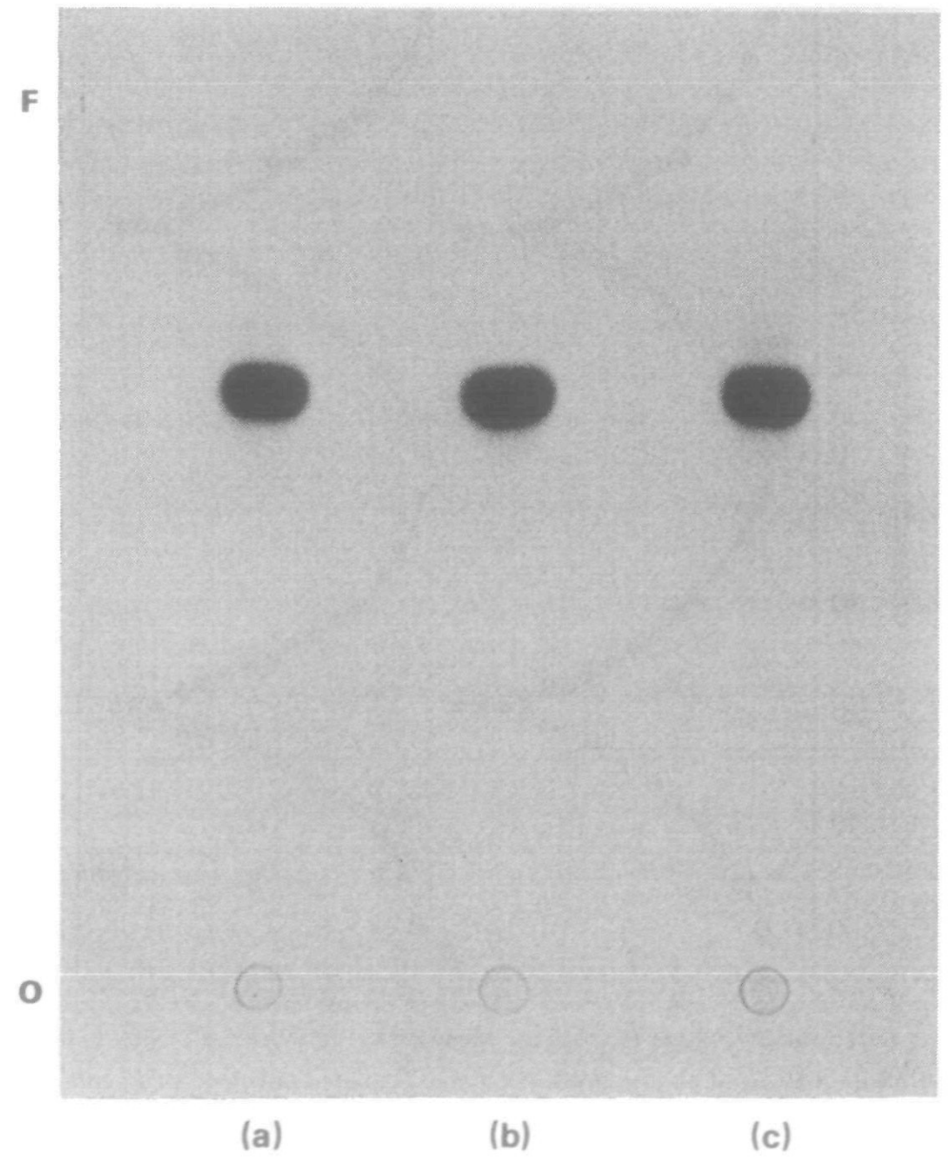

Figure 2. Autoradiographic demonstration of a thin layer chromatogram of chloramphenicol extracted from prelabelled cells of $E$. coli (a), $P$. aeruginosa (c), and of a control preparation of ${ }^{14} \mathrm{C}$-chloramphenicol (b). The designations $O$ and $F$ refer to origin and solvent front respectively. 


\section{Equilibrium dialysis}

As shown by Figure 3, chloramphenicol passed through the dialysis membrane without being bound by either non-growing cells or isolated cell envelopes.

\section{Uptake of amino-acids by cells preincubated in medium not supporting growth}

Figure 4 illustrates the time-course of the uptake of labelled amino-acids for both strains in a mineral solution at a concentration of 8.8 nanoatom carbon $/ \mathrm{ml}$. After $60 \mathrm{~s}$ of incubation, the preincubated cells of $E$. coli and $P$. aeruginosa accumulated labelled amino-acids, respectively 49.5 and 191.8 times over the external concentration, as determined on the basis of cell water (Winkler \& Wilson, 1966). Thereafter, the uptake reached a plateau over a period of measurements $(60-120 \mathrm{~s})$. The freshly washed cells of both strains accumulated amino-acids 1.3-1.5 times less than the preincubated cells. These results indicated that $2 \mathrm{~h}$ preincubation of cells in mineral solution did not significantly alter the active accumulation of amino-acids.

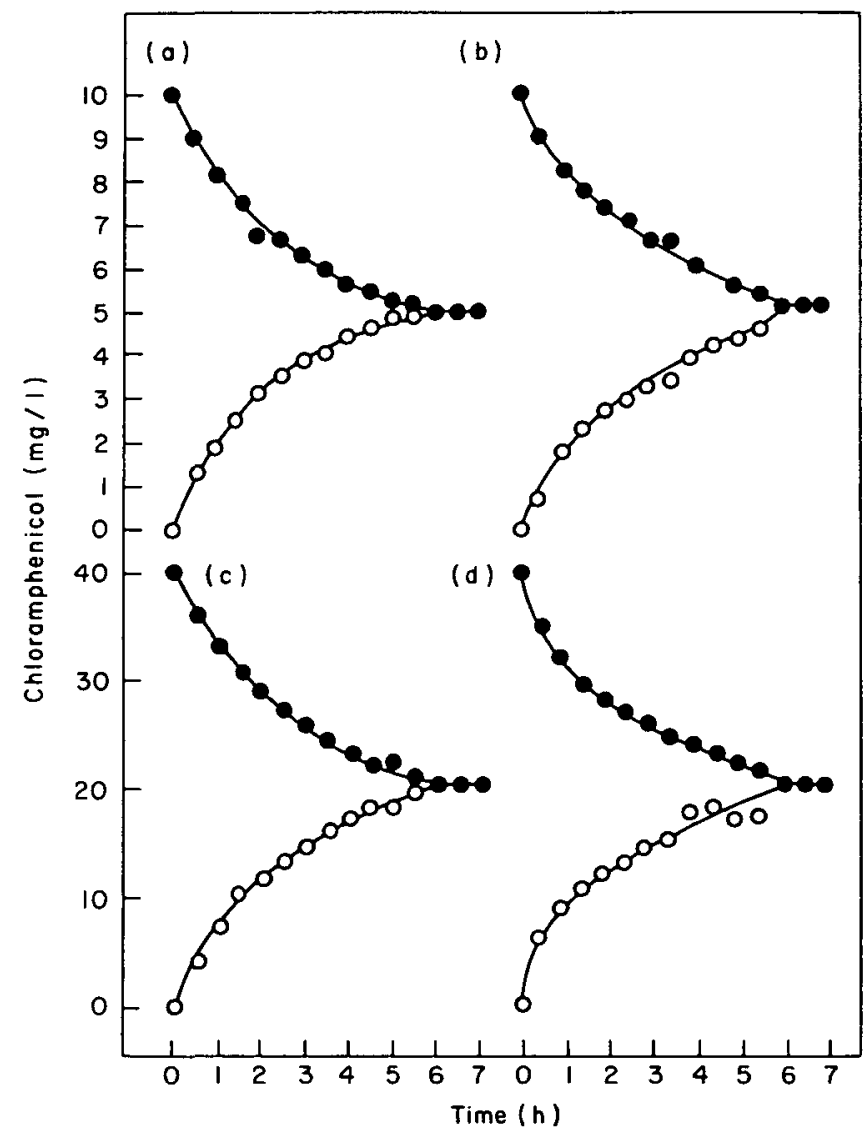

Figure 3. Equilibrium dialysis of chloramphenicol against isolated envelope of $E$. coli (a), cell envelope of $P$. aeruginosa (c), cells in non-growth conditions of $E$. coli (b), and $P$. aeruginosa (d). The dialysis chambers contained as appropriate: $0.5 \mathrm{mg}$ isolated envelope protein; $1 \mathrm{mg}$ cell protein; $0.031 \mathrm{~mm}$ chloramphenicol against isolated envelope or cells of $E$. coli; and $0.124 \mathrm{mM}$ chloramphenicol against isolated envelope or cells of $P$. aeruginosa. $O$, Radioactivity of samples taken from the compartments containing isolated envelope or cells; , radioactivity of samples taken from the compartments containing ${ }^{14} \mathrm{C}$-chloramphenicol. 


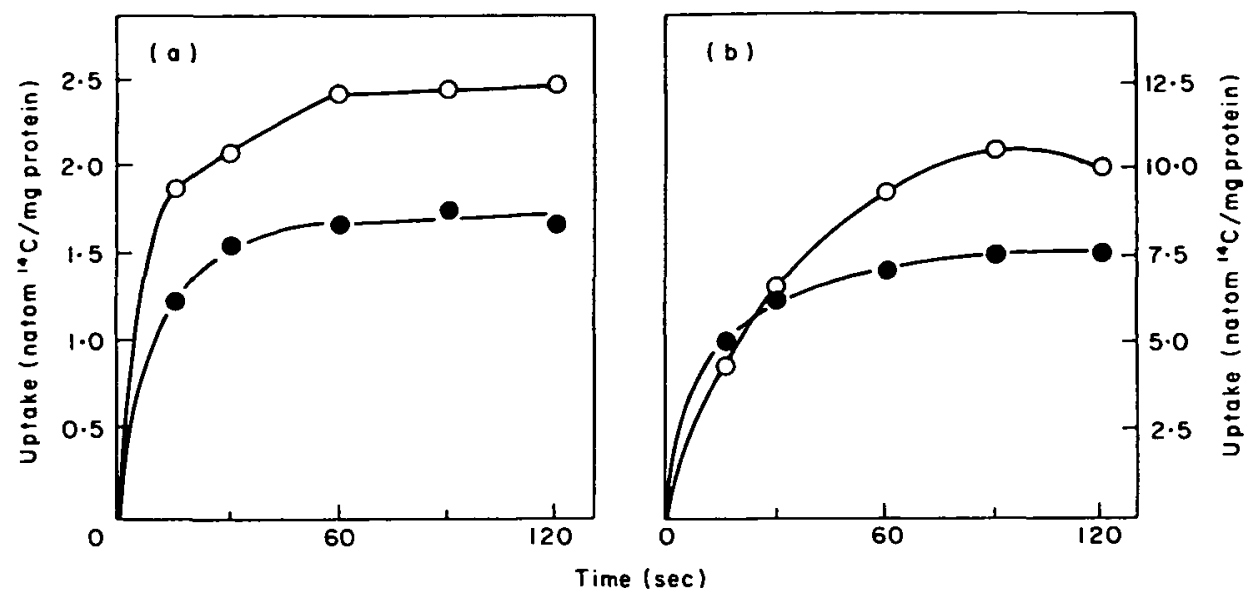

Figure 4. Uptake of $\left[\mathrm{U}^{14} \mathrm{C}\right]$ protein hydrolysate by cells preincubated in medium not supporting growth $(O)$, and freshly washed cells (O), of E. coli (a), and P. aeruginosa (b).

\section{Effect of energy inhibitors on chloramphenicol uptake}

Uptake of chloramphenicol was decreased or inhibited by a variety of energy inhibitors when added to the cells $5 \mathrm{~min}$ before the addition of chloramphenicol. As shown by Figure 5(a), cyanide and azide, inhibitors of electron transport (Lehninger, 1976) and arsenate, an inhibitor of high energy phosphate synthesis (Lehninger, 1976), all reduced to various degrees the rapid uptake by $E$. coli; thereafter, the cells progressively released the accumulated chloramphenicol into the supernatant. Rapid uptake by E. coli was insensitive to 2,4-dinitrophenol, an uncoupler of oxidative phosphorylation (Lehninger, 1976), but the cells were unable to maintain the chloramphenicol gradient; about $81 \%$ of the rapid uptake was released into the

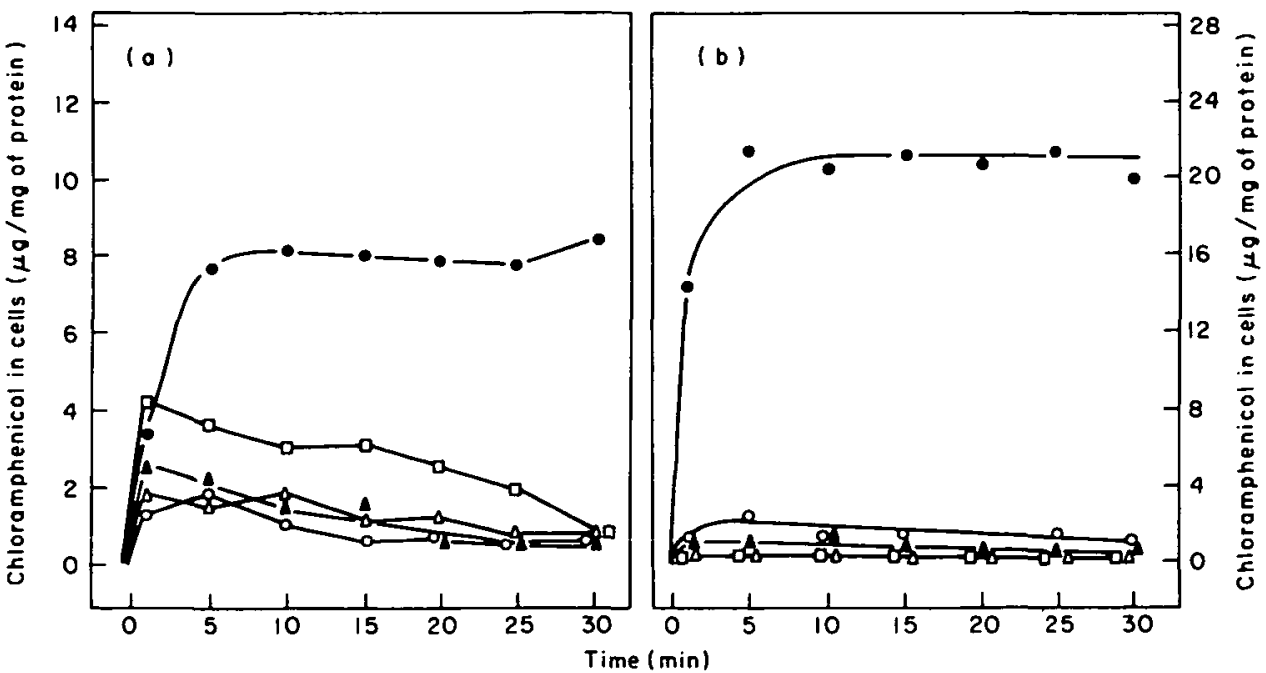

Figure 5. Effect of energy inhibitors on chloramphenicol uptake by $E$. coli (a), and $P$. aeruginosa (b), in the presence of $10 \mathrm{mg}$ and $40 \mathrm{mg}$ chloramphenicol $/ \mathrm{h}$, respectively. Cells preincubated for $5 \mathrm{~min}$ without any inhibitor ( () ), or individually with $1 \mathrm{mM}$ DNP $(\square), 2 \mathrm{mM} \mathrm{KCN}(\Delta), 5 \mathrm{~mm}$ azide $(\Delta)$, and $5 \mathrm{~mm}$ arsenate (O). 
Table III. Uptake of chloramphenicol by E. coli spheroplasts in sucrose phosphate buffer and sucrose BYGNaCl medium

\begin{tabular}{lc}
\hline Uptake medium & $\begin{array}{c}{ }^{14} \mathrm{C}-\mathrm{CM} \text { taken up } \\
(\mu \mathrm{g} / \mathrm{mg} \text { protein })\end{array}$ \\
\hline Sucrose phosphate buffer & $1 \cdot 20 \pm 0.44$ \\
Sucrose BYGNaCl medium & $0.71 \pm 0.26$ \\
\hline
\end{tabular}

-After $5 \mathrm{~min}$ of incubation in the presence of $10 \mathrm{mg} \mathrm{CM} / \mathrm{l}$. Values were obtained from three experiments.

supernatant within $29 \mathrm{~min}$. The inhibitors were more effective with $P$. aeruginosa than with E. coli. DNP and sodium azide completely inhibited the uptake of chloramphenicol by P. aeruginosa in both the rapid and the slow phases (Figure 5).

\section{Uptake of chloramphenical by spheroplasts in phosphate buffer}

Table III shows the uptake of ${ }^{14} \mathrm{C}$-chloramphenicol at $37^{\circ} \mathrm{C}$ by spheroplasts prepared from $E$. coli cells grown in $\mathrm{BYGNaCl}$ medium. After 5 min of incubation, the spheroplasts assayed in sucrose phosphate buffer incorporated chloramphenicol 1.6 times more than those assayed in sucrose $\mathrm{BYGNaCl}$ medium. These results clearly indicated, therefore, that the outer membrane and peptidoglycan deprived cells were not sensitive to the shift down of the environmental conditions and thus incorporated chloramphenicol even in phosphate buffer.

\section{Uptake as a function of chloramphenicol concentration in medium}

Measured after $1 \mathrm{~min}$, the uptake of chloramphenicol by $E$. coli and $P$. aeruginosa increased as the concentration in medium was increased from 40 to $640 \mathrm{mg} / \mathrm{l}$. Beyond

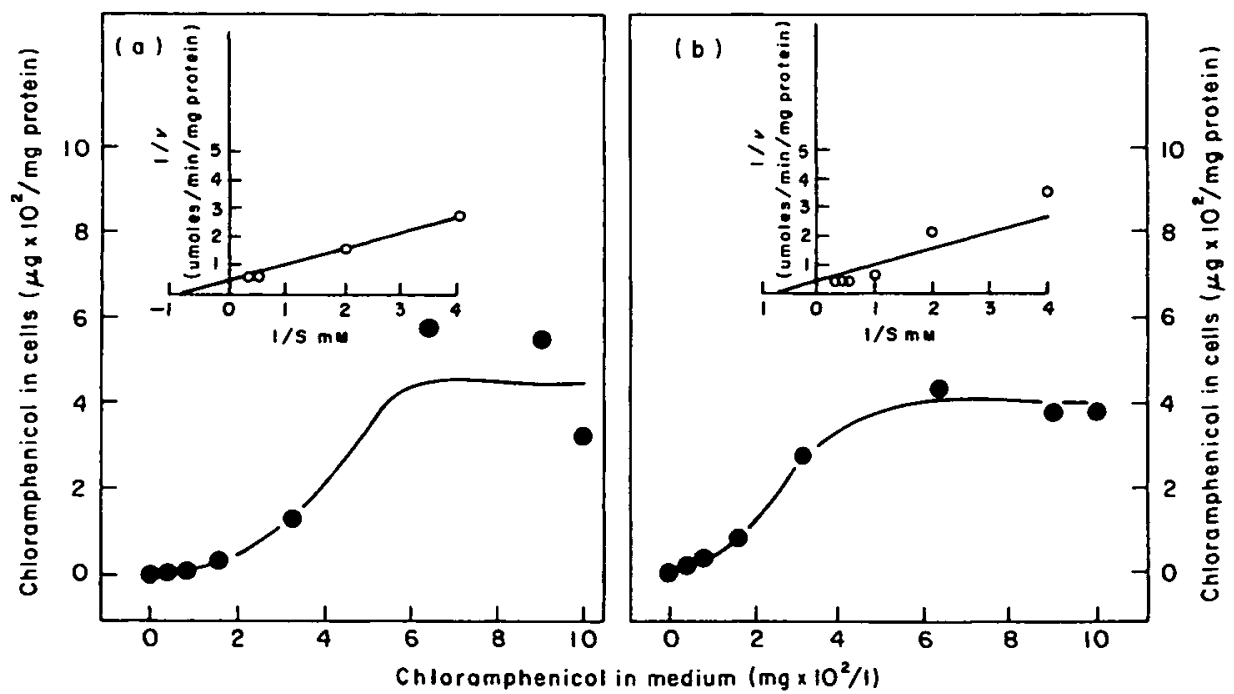

Figure 6. Uptake of chloramphenicol by $E$. coli (a), and $P$. aeruginosa (b), in $\mathrm{BYGNaCl}$ medium at various chloramphenicol concentrations. The inset is a Lineweaver-Burk plot of the kinetic data. 


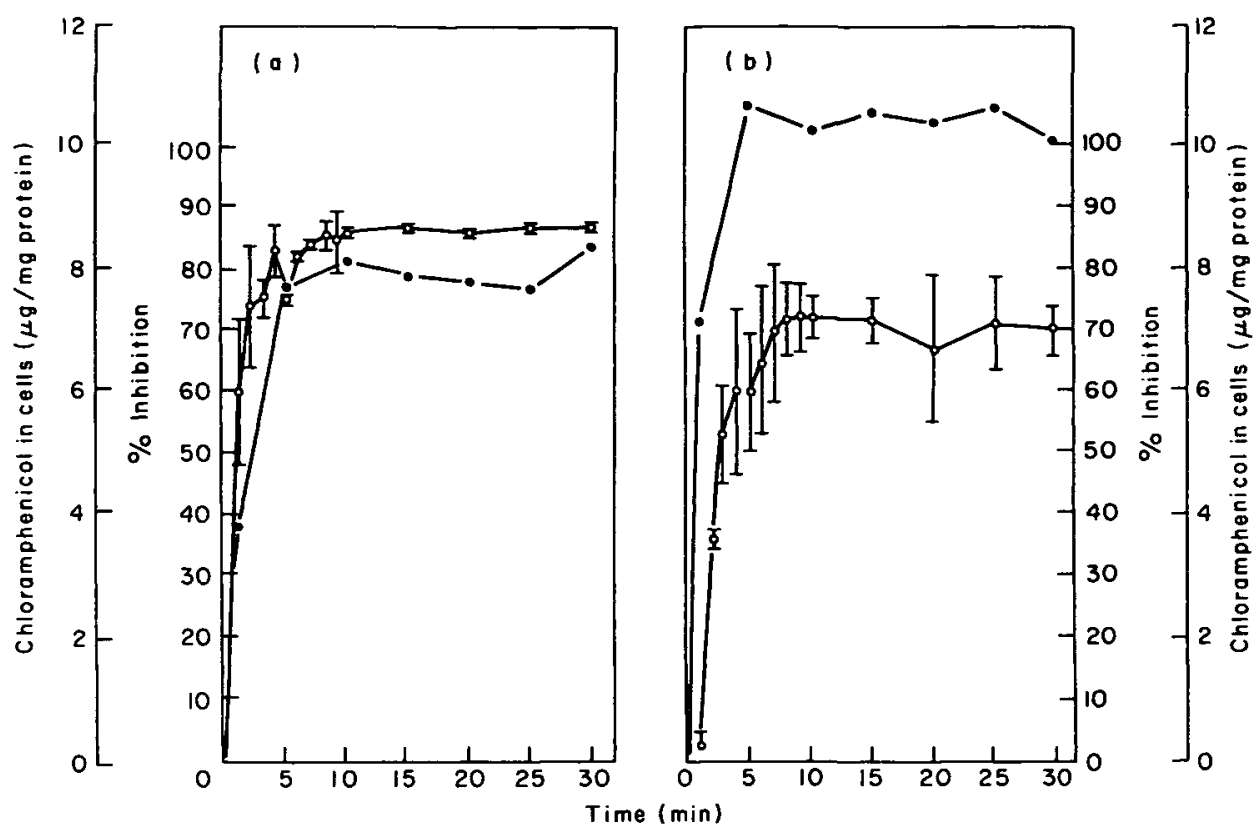

Figure 7. Relationship of chloramphenicol uptake $(O)$, to inhibition of protein synthesis $(O)$, in cells of $E$. coli at $10 \mathrm{mg}$ chloramphenicol/1 (a), and $P$. aeruginosa at $40 \mathrm{mg}$ chloramphenicol/1 (b). Bars represent standard errors of the mean for two experiments.

that range of concentration, the uptake by either strain of bacterium reached a plateau. A plot of the data in Lineweaver-Burk form revealed an apparent $K_{\mathrm{m}}\left(K_{t}\right)$ of $1.8 \mathrm{mM}$ and a $V_{\max }$ of $2.5 \mathrm{mmoles} / \mathrm{min} / \mathrm{g}$ protein, for both strains (Figure 6).

\section{Relationship of chloramphenicol uptake to inhibition of protein synthesis}

As shown by Figure 7 , when chloramphenicol was added simultaneously with ${ }^{35} \mathrm{~S}$-methionine to growing cells of $E$. coli, $60 \%$ inhibition of protein synthesis occurred within $1 \mathrm{~min}$; thereafter, an increasing inhibition occurred reaching $87 \%$ within $10 \mathrm{~min}$. For the $P$. aeruginosa strain, $53 \%$ inhibition occurred within $3 \mathrm{~min}$ and thereafter, an increasing inhibition reached $72 \%$ within 10 min. Thus, it seems that the rapid phase of chloramphenicol uptake was more effective with $E$. coli than with $P$. aeruginosa in inhibiting cellular protein synthesis.

\section{Discussion}

Our experimental results showed that chloramphenicol did not bind to either nongrowing cells or to isolated cell envelopes of $E$. coli and $P$. aeruginosa. Therefore, we measured the uptake of chloramphenicol by exponentially growing cells as the depletion of ${ }^{14} \mathrm{C}$-chloramphenicol from the supernatant of centrifuged cultures, assuming the missing ${ }^{14} \mathrm{C}$-chloramphenicol to be found within the cells. Filtration could not be used to collect cells because of the retention of label by membrane filters.

Hurwitz \& Braun (1967) proposed that chloramphenicol crosses the cytoplasmic membrane of $E$. coli by passive diffusion. This proposal was supported by data 
indicating that concentration of chloramphenicol by bacteria probably results from binding of the antibiotic to ribosomes (Harvey \& Koch, 1980). The results of the present study show that accumulation of chloramphenicol after $5 \mathrm{~min}$ by sensitive strains of $E$. coli and $P$. aeruginosa reaches respectively about 140 and 97 times the concentration in the medium. When the amount of ribosome-bound chloramphenicol, calculated on the basis of 26,000 ribosomes per cell (Goldstein \& Lowney, 1964) and one specific binding site per ribosome (Wolfe \& Hahn, 1965; Das, Goldstein \& Kenner, 1966; Hurwitz \& Braun, 1967), was subtracted from the total amount of cell-associated chloramphenicol, it appeared that chloramphenicol concentrations in the cell "pool" of $E$. coli and $P$. aeruginosa were respectively 136.3 and 96.5 times the concentration in the medium. Thus, these results clearly indicate that concentration of chloramphenicol by bacteria does not result simply from binding of the antibiotic to ribosomes, but that it is accumulated against a concentration gradient. Results reported here showed that chloramphenicol accumulation by either strain required energy, presumably to trạnsport chloramphenicol across the cytoplasmic membrane, since it is well recognized that ribosomal binding of chloramphenicol is not energy dependent (Vasquez, 1963, 1964).

Irvin \& Ingram (1982) pointed out that acquisition of chloramphenicol resistance in $P$. aeruginosa was a function of the concentration of free $\mathrm{Mg}^{++}$in the growth medium. The antagonism of chloramphenicol activity by $\mathrm{Mg}^{++}$was essentially immediate and was not a result of prolonged growth in $\mathrm{Mg}^{++}$limiting medium. More recently, however, Harvey \& Koch (1980) demonstrated that $\mathrm{Mg}^{++}$enhances in-vitro binding of chloramphenicol to ribosomes up to a concentration of $10 \mathrm{~mm}$. Our experimental results show that $\mathrm{Mg}^{++}$reduces the uptake of chloramphenicol and raises the MICs of the antibiotic for both strains of $E$. coli and $P$. aeruginosa. Thus, the effect of $\mathrm{Mg}^{++}$is the reverse of that noted on ribosomal binding. It is plausible, therefore, that the interaction of $\mathrm{Mg}^{++}$with the cell envelope of Gram-negative bacteria retards the movement of chloramphenicol across the cell envelope (diffusion through the outer membrane and subsequent transport across the cytoplasmic membrane). This in turn would permit bacterial growth in the presence of otherwise inhibitory concentrations of chloramphenicol.

The results reported here demonstrate that the accumulation kinetics of chloramphenicol are biphasic: an initial rapid phase and a second slower phase. In addition, uptake of the drug measured in minimal BM2 medium is much less than that measured in enriched medium. These findings agree with those previously reported by Vasquez (1966) with Gram-positive bacteria. However, our results indicate that unlabelled chloramphenicol isomers effectively prevent the uptake of ${ }^{14} \mathrm{C}$-chloramphenicol (Table I); in other words, the isomers compete with chloramphenicol in cellular penetration. These findings do not agree with those previously reported by Vasquez (1966) with Gram-positive bacteria. He demonstrated that unlabelled chloramphenicol isomers: L-threo, D-erthryo, and L-erythro did not reduce the uptake of ${ }^{14} \mathrm{C}$-chloramphenicol by $B$. megaterium after $15 \mathrm{~min}$ of incubation with the drug; but the uptake of ${ }^{14} \mathrm{C}$-chloramphenicol was reduced by $77.9 \%$ when unlabelled chloramphenicol was added at ten times the concentration of ${ }^{14} \mathrm{C}$-chloramphenicol. However, it is doubtful that chloramphenicol uptake could be measured accurately by washing the cells twice with $15 \mathrm{ml}$ of $10 \mathrm{~mm}$ Tris-HCl buffer. Most probably washing the cells removed most of the unbound chloramphenicol from the bacterial "pool" and the apparent reduction of uptake of ${ }^{14} \mathrm{C}$-chloramphenicol 
could be explained by competition between the labelled and unlabelled molecules for binding to ribosomes. The lack of effect of chloramphenicol isomers was most probably due to inability of isomers to prevent stereospecific binding of chloramphenicol. Vasquez (1966) showed in his studies that all the compounds which inhibit uptake of chloramphenicol by intact bacteria, with the exception of ostreogrycins B group, also prevent binding of chloramphenicol to bacterial ribosomes in a cell-free system.

Cells grown in BYGNaCl and assayed in BM2 medium do not transport chloramphenicol. Such cells, when transferred to BM2 medium, exhibited a lag period over $6 \mathrm{~h}$ before the growth initiation. During the lag period the cells do not incorporate chloramphenicol. During growth in BM2 medium, they incorporate chloramphenicol, but however at a lower rate than in $\mathrm{BYGNaCl}$ medium. Cells transferred from $\mathrm{BYGNaCl}$ or from $\mathrm{BM} 2$ medium to phosphate buffer do not incorporate chloramphenicol. These results indicate that non-growing cells do not transport chloramphenicol. However, such cells actively accumulate amino-acids even after $2 \mathrm{~h}$ of preincubation in medium unable to support growth (Figure 4). Thus, the failure of non-growing cells to transport chloramphenicol cannot simply be attributed to loss of energy coupling for uptake. The data reported here demonstrate that spheroplasts prepared from cells grown in BYGNaCl medium and assayed in phosphate buffer transport chloramphenicol slightly more than those assayed in BYGNaCl medium. These findings clearly indicate that the permeability barrier to chloramphenicol in non-growing cells is located outside the cytoplasmic membrane.

Nakae \& Nikaido (1975) demonstrated that the outer membrane does act as a limiting barrier for the penetration of hydrophilic substances, but not the peptidoglycan. Although chloramphenicol is relatively hydrophobic, it penetrates the outer membrane of Salmonella typhimurium and E. coli via aqueous (porin) pathways (Nikaido, 1976; Chopra \& Eccles, 1978; Pugsley \& Schnaitman, 1978). The data presented here suggest that diffusion of chloramphenicol across the outer bacterial membrane depends on active growth. It seems possibly a conformational change occurs in non-growing cells that prevents chloramphenicol recognizing the porin channels.

\section{Acknowledgements}

I am grateful to Professor Valentin Bonifas for discussions and for critical reading of this manuscript. The able technical assistance of Hong Fritschy and France Schmid is acknowledged.

\section{References}

Anraku, Y. (1978). Active transport of amino acids. In Bacterial transport (Rosen, B. P., Ed.), p. 171. Marcel Dekker, New York.

Chopra, I. \& Eccles, S. J. (1978). Diffusion of tetracycline across the outer membrane of Escherichia coli K-12: Involvement of protein $\mathrm{I}_{\mathrm{a}}$. Biochemical and Biophysical Research Communications 83, 550-7.

Das, H. K., Goldstein, A. \& Kenner, L. C. (1966). Inhibition by chloramphenicol of the growth of nascent protein chains in Escherichia coli. Molecular Pharmacology 2, 158-70.

Foster, T. J. (1983). Plasmid-determined resistance to antimicrobial drugs and toxic metal in bacteria. Bacteriological Reviews 47, 361-409. 
Foulds, J. \& Chai, T. J. (1978). New major outer membrane protein found in an Escherichia coli to $1 \mathrm{~F}$ mutant resistant to bacteriophage Tulb. Journal of Bacteriology 133, 1478-83.

Furlong, C. E., Morris, R. G., Kandrach, M. \& Rosen, B. P. (1972). A multichamber equilibrium dialysis apparatus. Analytical Biochemistry 47, 514-26.

Gilleland, H. E., Stinett, J. D. \& Eagon, R. G. (1974). Ultrastructural and chemical alterations of the cell envelope of Pseudomonas aeruginosa associated with resistance to ethylenediamine-tetraacetate resulting from growth in $\mathrm{Mg}^{++}$-deficient medium. Journal of Bacteriology 117, 302-11.

Goldstein, A. D. B. \& Lowney, L. I. (1964). Protein synthesis at $0^{\circ} \mathrm{C}$ in Escherichia coli. Journal of Molecular Biology 9, 213-35.

Hancock, R. E. W. \& Nikaido, H. (1978). Outer membranes of Gram-negative bacteria. XIX. Isolation from Pseudomonas aeruginosa PA01 and use in reconstitution and definition of the permeability barrier. Journal of Bacteriology 136, 381-90.

Harvey, R. J. \& Koch, A. L. (1980). How partially inhibitory concentrations of chloramphenicol affect the growth of E. coli. Antimicrobial Agents and Chemotherapy 18, 323-37.

Hurwitz, C. \& Braun, C. B. (1967). Measurement of binding of chloramphenicol by intact cells. Journal of Bacteriology 93, 1671-6.

Irvin, J. E. \& Ingram, J. M. (1980). Chloramphenicol-resistant variants of Pseudomonas aeruginosa defective in amino acid transport. Canadian Journal of Biochemistry 58, 1165-71.

Irvin, J. E. \& Ingram, J. M. (1982). Divalent cation regulation of chloramphenicol resistance in Pseudomonas aeruginosa. FEMS Microbiology Letters 13, 63-7.

Lehninger, A. I. (1976). Biochemistry, p. 495. Worth Publishers, New York.

Lennox, E. S. (1955). Transduction of linked genetic characters of host by bacteriophage PI. Virology 1, 190-206.

Levy, S. B. (1971). Physical and functional characteristics of $\mathbf{R}$-factor deoxyribonucleic acid segregated into Escherichia coli minicells. Journal of Bacteriology 108, 300-8.

Markwell, M. A. K., Haas, S. M., Birber, L. L. \& Tolbert, H. E. (1978). A modification of the Lowry procedure to simplify protein determination in membrane lipoprotein samples. Analytical Biochemistry 87, 206-310.

Nakae, T. \& Nikaido, H. (1975). Outer membrane as a diffusion barrier in Salmonella typhimurium. Journal of Biological Chemistry 250, 7359-65.

Nierhaus, D. \& Nierhaus, K. H. (1973). Identification of the chloramphenicol-binding protein in Escherichia coli ribosomes by partial reconstitution. Proceedings of the National Academy of Sciences U.S.A. 70, 2224-8.

Nikaido, H. (1976). Outer membranes of Salmonella typhimurium: Transmembrane diffusion of some hydrophobic substances. Biochimica et Biophysica Acta 433, 118-32.

Pugsley, A. P. \& Schnaitman, C. A. (1978). Outer membrane proteins of Escherichia coli: VII. Evidence that bacteriophage-directed protein 2 functions as a pore. Journal of Bacteriology 133, 1181-9.

Vasquez, D. (1963). Antibiotics which affect protein synthesis: The uptake of ${ }^{14} \mathrm{C}$ chloramphenicol by bacteria. Biochemical and Biophysical Research Communications 12, 409-13.

Vasquez, D. (1964). Uptake and binding of chloramphenicol by sensitive and resistant organisms. Nature 203, 257-8.

Vasquez, D. (1966). Binding of chloramphenicol to ribosomes. The effect of a number of antibiotics. Biochimica et Biophysica Acta 114, 277-88.

Weiss, R. L. (1976). Protoplast formation in Escherichia coli. Journal of Bacteriology 128, 668-70.

Winkler, H. H. \& Wilson, T. H. (1966). The role of energy coupling in the transport of $\beta$ galactosides by Escherichia coli. Journal of Biological Chemistry 241, 2200-11.

Wolfe, A. D. \& Hahn, F. E. (1965). Mode of action of chloramphenicol IX. Effects of chloramphenicol upon a ribosomal amino acid polymerization system and its binding to bacterial ribosome. Biochimica Biophysica Acta 95, 146-5.

(Manuscript accepted 22 May 1980) 